\title{
The Vanishing Acheron House of Refuge: A Case of "Frontier Chaos"?
}

\author{
Clare Kelly, Architect, Christchurch
}

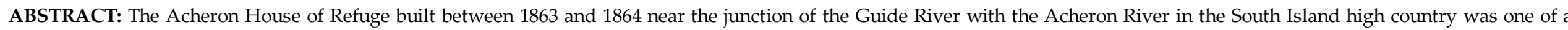

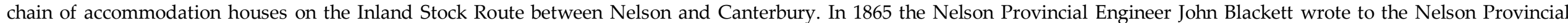

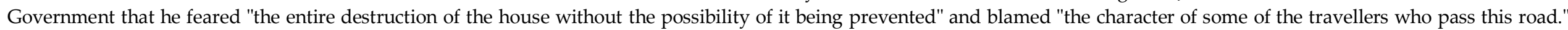
By the end of 1865 , it was destroyed without trace.

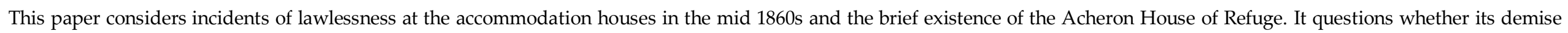

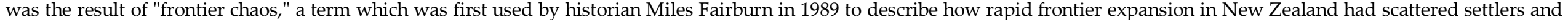

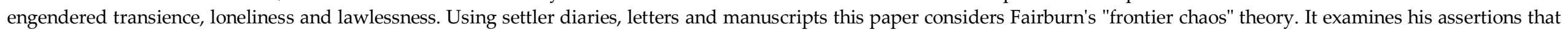

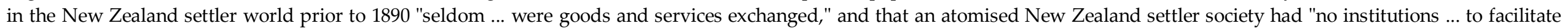
mixing and meeting" (Fairburn "Local Community or Atomised Society?" pp 169-170,192,195,206,217).

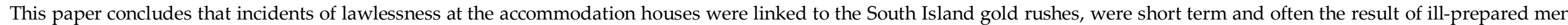

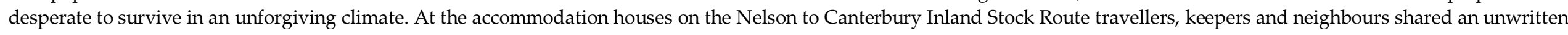
code of reciprocity. These accommodation houses formed the unofficial nuclei of small, loose-knit high country communities.

\section{Introduction}

Historian Jock Phillips wrote that "colonising elites nearly always like to see their role in history as bringing civilisation to the wilderness. Their corresponding fear is that the wilderness might prove too powerful." ${ }^{1}$ While New Zealand histiography changed and developed ${ }^{2}$ between the nineteenth and twentieth century, most held that civilisation had triumphed over anarchy. Then in 1989, in a book described as "undoubtedly one of the

${ }^{1}$ Phillips A Man's Country? p 47.

${ }^{2}$ Olssen "Mr Wakefield and New Zealand as an Experiment" pp 54-67. most important recent works in Pakeha historiography,"3 historian Miles Fairburn proposed that rapid frontier expansion had scattered settlers and engendered transience, loneliness and (most provocatively) lawlessness. In The Ideal Society and its Enemies: The Foundations of Modern New Zealand Society 1850-1900, Fairburn contended that conditions of early settlement led to loneliness ${ }^{4}$ and this in turn to a disproportionate rate of drunkenness and violence, part of a greater pattern of "frontier chaos." Fairburn's work

${ }^{3}$ Daley "Taradale Meets the Ideal Society" p 129.

${ }^{4}$ Fairburn The Ideal Society pp 195,206,217. was both lauded and criticised by historians. Rollo Arnold countered Fairburn's argument and claimed that "New Zealand's founding stock was drawn predominantly from village life of the Old World" 5 and that settlers worked co-operatively to establish new districts. Others challenged both Fairburn's use of statistics, the relevance of using statistics to gauge concepts of social bonding, ${ }^{6}$ and the validity of applying this theory to every region of New Zealand. ${ }^{7}$ One study

\footnotetext{
${ }^{5}$ Arnold New Zealand's Burning p 118

${ }^{6}$ Daley "Taradale Meets the Ideal Society" p 131
}

${ }^{7}$ McAloon "James Jenkins Lecture" pp 9-10. 
showed that even the notoriously footloose male bush-felling gangs of the upper North Island frontier worked with a high level of mutual support and social organization. ${ }^{8}$

This paper's context is the high country between Nelson and Canterbury, the South Island frontier. Its focus is the accommodation houses on the Nelson to Canterbury Inland Stock Route established by the Nelson Provincial Government in the early 1860s. Between 1863 and 1865 at the height of the South Island goldrushes, they were besieged by a wave of lawlessness and the Acheron House of Refuge was completely destroyed. This paper uses settler diaries, letters and manuscripts from these accommodation houses to question whether these buildings were victims of "frontier chaos;" had the wilderness proved too powerful?

\section{Civilisation in the Wilderness}

Attaining "civilisation" was a central ideal of British colonising ventures from the sixteenth

8Duncan McKay's study of the kauri bushmen of the upper North Island between 1860 and 1925 showed how they developed a resilient common culture with work patterns that fostered "solidarity rather than

atomisation." MacKay "The Orderly Frontier" pp 147148. century onwards. ${ }^{9}$ By 1860 the South Island of New Zealand comprised a series of provinces the foundations of which were based on, or influenced by the theories of systematic colonisation of Edward Gibbon Wakefield. ${ }^{10}$ Committed to a belief that civilisation could be successfully transplanted, Wakefield sought to avoid both the ills of frontier society ${ }^{11}$ (binging, boozing, violence and prostitution) and the injustices of Old World capitalism. ${ }^{12}$ The towns of each settlement were to be modeled on English medieval villages, centres of civilisation surrounded by small agricultural farms. Unlike English villages however, these "main towns" were laid out on a grid plan. While 1860s maps of South Island cities read as images of settlement contained and civilisation ensured, the reality was far more tentative.

The 1860s was the "great era of Canterbury

${ }_{9}^{9}$ Burnard "An Artisanal Town" p 117.

${ }^{10}$ Nelson, Canterbury and Dunedin were either New Zealand Company settlements or significantly influenced by the ideals of Edward Gibbon Wakefield. The West Coast separated from Canterbury in 1852 and by 1860 Marlborough had separated from Nelson. ${ }_{11}$ Olssen "Mr Wakefield and New Zealand as an Experiment" p 205.

12 Olssen "Mr Wakefield and New Zealand as an Experiment" p198. pastoralism"13 and rather than Wakefield's "main town," Christchurch's significance lay as the centre of the Canterbury Province. The city remained predominantly swamp or groves of tussock and toi toi and key streets within the town reserves had little or no building. ${ }^{14}$ By the mid 1860s progress had been made ${ }^{15}$ and significantly in 1865 Edward Dobson produced a map for the drainage of the city ${ }^{16}$ which heralded the erasure of Ngāi Tahu cultural landscape and provided the palimpsest for "English"17 Christchurch of the decades that followed. Economic progress was the portent of civilisation and in the 1860s it was the roads from Christchurch city to the north and south, the rail network and tunnel to port that provided the tangible promise of that progress. The Christchurch to Ferrymead

13 1857- 1868. Scotter "The Superintendencies of Moorhouse and Bealy" p 178.

${ }^{14}$ See for example Fooks "Map of Christchurch, Canterbury, New Zealand 1862."

${ }^{15}$ The first buildings of Christs College had been built, the foundation stone for the Provincial Government building laid and Von Haast began his collection for the Canterbury Museum. By the mid 1860s a hospital and a number of churches including St Michael's Anglican,

Durham St Methodist, and St John's Church, had been built. Morrison The Evolution of a City $\mathrm{p} 21$.

${ }^{16}$ Morrison The Evolution of a City p 50.

${ }_{17}$ Cookson "Pilgrims' Progress" p 28. 
rail line was opened in 1863 and branch lines to outlying districts soon followed. ${ }^{18}$ In 1861 Moorhouse turned the first sod at Heathcote for the Lyttleton Rail Tunnel. It was opened in 1867. As settlement grew along rail routes outside the town belt (e.g. Woolston and Addington) and there was little architecture of apparent permanence within, Christchurch in the 1860s bore little resemblance to Wakefield's vision. As its roads and railway bore wool bales to port, it was however, a conduit of progress.

Nelson settlers considered themselves "shut up within the horseshoe of Blind Bay"19 and by the1860s the Hope, Gordon and Arthur Ranges still remained a barrier between the city and its pastoral hinterland. Only $40 \%$ of Nelson's population lived in the city, the landscape and absence of landowners having created "thriving village communities"20 in the outlying agricultural districts. While this dispersal of settlement was in part the result of the failings of the Wakefield plan in Nelson, ${ }^{21}$ these agricultural villages became "paradoxically the nearest approach to English

${ }^{18}$ Morrison The Evolution of a City pp 46-47.

19 "The Nelson Examiner: Nelson, April 6, 1850"p 2

${ }^{20}$ McAloon Nelson p 81.

${ }^{21}$ Gardner The Amuri p 7. villages as hoped for by Godley."22 Nelson city's buildings were predominantly timber, many sites remained vacant and city drainage was inadequate ${ }^{23}$ but Nelson had become an important port. At the beginning of the 1860s roads carried wool then gold to port and by the end of the decade became a conduit of imports back to the goldfields. ${ }^{24}$ As with Christchurch in the 1860s, Nelson city's capital works were a tangible image of progress and progress was the vanguard of civilisation.

\section{The Pastoral Hinterland}

Both the Wairau Valley and the Canterbury plains, foothills and high country were ideally suited to extensive pastoral farming but the consequent dispersal of settlement was anathema to Wakefield's vision of a transplanted English countryside. When the Canterbury Settlement Lands Amendment Act was passed in $1851^{25}$ he had warned, it would lead to "barbarism and squatting."26 Yet by the 1860s in Nelson province (outside Blind Bay) and Canterbury, Wakefield's arcadian

\footnotetext{
${ }^{22}$ Gardner The Amuri p 7

${ }^{23}$ McAloon Nelson p 85.

24 McAloon Nelson pp 83-84.

${ }^{25}$ Webb "The Canterbury Association" p 194.

${ }^{26}$ Webb "The Canterbury Association" p 197.
}

vision of "corn crammed parallelograms" 27 was largely replaced by isolated pastoral runs. Settlement lacked recognisable terrain, pattern or vegetation and appeared as wilderness to the English eye. Friends of Nelson's first Anglican bishop, Hobhouse, wrote back to England describing this landscape to prospective clerics and immigrants:

The whole of the rest of the diocese [of Nelson] behind the V-shaped wall of mountains that enclose Blind Bay is either forest, ferndom, or sheep-run, inhabited only in the latter case and that of necessity, sparsely. ${ }^{28}$

Not only the high country but the raw scale of the foothills and vast open spaces of the plains challenged settler sensibilities. ${ }^{29}$ Occasionally a traveller would see evidence of human habitation; station buildings. However, even the relationship of these buildings was unfamiliar. In Europe, farm buildings were usually clustered around courtyards to protect stock in winter. In Nelson and Canterbury, a system of pre-emptive rights existed to prevent leaseholders from losing improvements if their farm was sold. ${ }^{30}$ The

\footnotetext{
${ }^{27}$ Miller Early Victorian New Zealand p 135.

${ }^{28}$ Hobhouse An Account of Nelson p 16.

${ }^{29}$ Barker Station Life p 76.

${ }^{30}$ In Canterbury a leaseholder could apply for pre-
} emptive rights over 250 acres around a homestead and 
most visible difference to the new settler's eye between the English countryside and this (South Island) high country landscape was the dispersed pattern of strategically located farm buildings on key (valuable) parts of the run. ${ }^{31}$

Roads were a necessity for trade and in 1850 the Nelson Examiner had declared,

One of the subjects of the greatest importance to every country, is its means of internal communication. However fertile may be the soil, whatever may be its advantages in other ways, without good roads, and the facilities of communicating with markets, a country will always be retarded in material wealth, as well as social improvement."32

Despite this, in the pastoral hinterland roads were few and of poor upkeep. In 1855 explorer and pastoralist, Fredrick Weld discovered a route through the inland high country between Nelson and Canterbury

50 acres around other improvements, outstations, plantations and fencing. Along with fencing and increasing stock numbers to fulfil leasehold stocking conditions, pre-emptive purchase became a key financial priority for leaseholders. Scotter "The Superintendencies of Moorhouse and Bealy" p 190.

${ }^{31}$ Scotter "The Superintendencies of Moorhouse and Bealy" p 195.

32 "The Nelson Examiner: Nelson, January 26, 1850" p 2. provinces. "The sheep highway to the south,"33 in good weather, reduced the journey between Nelson and Canterbury to six days and became a key trade route supplying muchneeded livestock from overstocked Wairau runs to their under-stocked Canterbury counterparts. For those trading stock or travelling between the provinces, the route rose in altitude from nearly 600 metres at the Tophouse Pass to about 1000 metres at the Tarndale flats and necessitated numerous river crossings. Even in summer, high winds often gusted in the valleys and temperatures could fall below freezing at night. As use of the route increased with the stocking of the high country runs, so too did the incidence of drowning. Indeed, settlers came to regard drowning as a "natural" cause of death. ${ }^{34}$

From the early 1860s gold rush traffic increased through the Wairau Valley and on the Nelson to Canterbury Inland Stock Route. This challenged a tradition of station owner hospitality to travellers and pastoralist George Rutherford warned the Nelson Superintendent that there were "many bad characters moving about in these digging

\footnotetext{
${ }^{33}$ Gardner The Amuri p 4.
}

34 "Death by Drowning" p 3. times." ${ }^{35}$ Rutherford's petition joined a chorus of public admonition to Nelson Provincial Government to establish accommodation houses. In response, the second Tophouse Accommodation House $^{36}$ and Jollies Pass Accommodation House were built in 1862, ${ }^{37}$ Tarndale Accommodation House, ${ }^{38}$ the Acheron Accommodation House ${ }^{39}$ and Morris' Accommodation House (Waiau) in 1863, ${ }^{40}$ Acheron House of Refuge in 1864 and Barnett's Accommodation House (Hurunui North Bank) in 1865. ${ }^{41}$

A sum of money was voted by Provincial Council for construction of each accommodation house and paid to the keeper on completion. Local availability of materials and budget dictated construction and most

35 George Rutherford to Superintendent, 2 September 1863, NP 7 1863/666 (SPN).

${ }^{36}$ Adolphe Wiesenhavern to the Superintendent, 27 July 1862, NP 7 1862/395 (SPN)

${ }^{37}$ Count de la Pasture to the Superintendent, 3

November 1862, NP 7 1862/599 (SPN).

${ }^{38} \mathrm{~W}$. White to the Superintendent, January 1863, NP 7 1863/42 (SPN)

${ }^{39}$ Diary of J.C. Richmond 1863 p 12.

${ }^{40} \mathrm{~J}$. W. Morris to the Superintendent, 5 October 1864, NP 7 1864/751 (SPN).

${ }^{41} \mathrm{~W}$. Barnett to the Superintendent, 14 December 1865 , NP 7 1865/808 (SPN). 
accommodation houses on the Inland Stock Route were built of cob. The size of each accommodation house was determined by the number of rooms (bedrooms and sitting rooms) stipulated by the license, the number of horses to be stabled and size of enclosure for stock. The lessee was required to provide meals, clean beds for travellers and oats or oaten hay for horses at charges stipulated by the licence.

While conditions of upkeep varied, generally travellers entered a dimly lit room with cob walls. Minimal openings deadened the sound of mountain winds. The (smoky) fireplace offered the opportunity to dry damp clothing and drink billy tea while confronting the prospect of an evening's close proximity with fellow travellers. John Gully's sketch of the Tarndale sitting room shows the simple shelter of cob walls, rough sawn beech framing, loose fit floorboards and a large central fireplace. ${ }^{42}$ (An outdoor bake oven can be seen in the background). Snow grass thatch was used as roof cladding at both the Tarndale and the second Tophouse and probably contributed to JC Richmond's observation that his bedroom "was about as

${ }^{42}$ Gully "Interior of Tarndale Accommodation House" weather tight as a four-rail fence."43 The Acheron Accommodation House had a corrugated iron roof, which in combination with its deep verandah and good site drainage contributed to its longevity.

The stock route was a bridle path defined by a plough and furrow line and frequently washed out by flooding, broken up by stock movement or obliterated by snow. Despite this it was a conduit of progress, an important perceptual line through what remained in the 1860s, an unknown wilderness. Established at one day's journey apart, the cob accommodation houses became landmarks and generally provided welcome shelter at the end of a day's journey. For isolated run holders, several days ride from a centre of law enforcement they also offered the prospect that the "bad characters" travelling to the goldfields wouldn't visit their homesteads, sleep in their outbuildings or slaughter their livestock for food.

In the early 1860s Nelson goldfields at Golden Bay and Wangapeka provided modest returns. The West Coast goldrushes began in early 1863 with a rush to the Lyell (a tributary

${ }^{43}$ Diary of J. C. Richmond 1863 pp 7-8. of the Buller) and by 1864 the upper Buller, Lyell and Matakitaki diggings were thriving. The focus then turned to Wakamarina in Marlborough. ${ }^{44}$ For accommodation house keepers during this period, traveller numbers and behaviour became a significant challenge. The keeper of the Tarndale Accommodation House, William White complained to the Superintendent about

the number of Travellers passing to and from Otago Canterbury and Nelson 9/10 of whom not only cannot pay for what they eat at the house but has [sic] to be assisted in the shape of stores to carry them on the road the stronger parties (very often 16 or 18 of a night) demanding and the weaker parties begging the same.

The situation under which I am placed renders it absolutely necessary to appeal to your honours Govt [sic] for assistance either in the shape of protection that I might be enabled to resist the demands of the hordes who are continually travelling through the country or pecuniary assistance say $2 / 6$ per meal for all those who cannot pay or are strong enough to enforce their demands. ${ }^{45}$

The "hordes" were not only demanding on food supplies. The Nelson Provincial Engineer, John Blackett reported to Provincial

${ }^{44}$ McAloon Nelson pp 74-75.

${ }^{45} \mathrm{~W}$. White to the Superintendent, 13 November 1863, NP 7 1863/952 (SPN). 


\section{Council in early 1865 that:}

two years ago the most wanton destruction of food furniture and cooking utensils (although left there for the use of travellers) took place both at Tarndale and the House on the Clarence Acheron Junction; one party appeared to have used and carried away as much food as they could, and then scattered the remainder on the ground besides rendering useless all vessels for cooking and drinking and smashing and burning the furniture. ${ }^{46}$

While this vandalism taking place several days' journey from any centre of law enforcement was both costly and traumatic for accommodation house keepers, provincial officials were confronted even more apparently wanton destruction at the Acheron House of Refuge.

\section{The Vanishing Acheron House of Refuge}

In 1862 the Nelson Provincial Council voted expenditure for $£ 300$ for a House of Accommodation, and $£ 100$ for a House of Refuge in the Acheron Valley. ${ }^{47}$ The Acheron House of Refuge was to be built in a convenient place near the junction of the

${ }^{46}$ John Blackett: Provincial Engineer, NVP, 1865, a 13-65. 47 Details of Proposed Expenditure of the Province of Nelson as Voted by the Provincial Council for the Year commencing on the 1 April 1862, NVP 1862.
Guide and Acheron Rivers. ${ }^{48}$ The considerably more modest budget and brief for the House of Refuge probably reflected the Nelson Provincial Government's unwillingness to commit to expenditure on a site that would be used equally by travellers on the Inland Stock Route and the original but longer route of travel via Barefell Pass, still used by those travelling from Marlborough. The Provincial Secretary cited the enclosure of sketches of both the "Acheron Accommodation House" and the "House of Refuge" and proposed that Thomas Carter choose the exact site on the reserve for the House of Refuge. He should prioritise "the facility of obtaining Cob for the walls and chimneys, the ready access to a supply of water and also of firewood and choose a comparatively sheltered situation." 49 Acknowledging that when built, the house was not intended to have a keeper in residence, the letter also suggested that "grass and other combustible material ought to be cleared away for a considerable space around it to prevent accident by fire." The letter was clear that Carter was to "devote sufficient time" to looking after the running of the

${ }^{48}$ The Provincial Secretary to Thomas Carter, 8 October 1862, NP 11/4 1862/395 (OSePN).

${ }^{49}$ The Provincial Secretary to Thomas Carter, 8 October 1862, NP 11/4 1862/395 (OSePN).
House of Refuge. Carter wrote to the Superintendent in April 1864 informing him that it was now nearly complete and requesting payment. ${ }^{50}$

The sketch accompanying the Provincial Secretary's letter of commission was not duplicated and the size and spatial layout of the House of Refuge cannot be confidently confirmed. It was likely to have had a space for sleeping and sitting, with a fireplace to have been kept supplied with firewood, a store-room and to have been about $1 / 3$ the size of the Acheron Accommodation House, with a timber framed verandah. It can not be inferred whether there was any cooking facility (e.g. external bake oven) other than a fireplace. ${ }^{51}$

While numerous accounts of journeys through the Inland Stock Route were published in provincial newspapers between 1864 and the mid 1890s, only an item in the Provincial Engineer's Report in 1865 and one in an accompanying enclosure leave any record of the eventual fate of the Acheron House of

50 Thomas Carter to the Superintendent, 3 April 1864, NP 7 1864/303 (SPN).

${ }^{51}$ A sleeping and sitting space with a fireplace and a store-room were common to all the accommodation houses on the Nelson to Canterbury Inland Stock Route. 
Refuge. John Blackett, the Provincial Engineer wrote:

This [report] refers to the House of Refuge erected in the Acheron Valley, the difficulty of getting firewood here readily, will I fear lead to the entire destruction of the house without the possibility of it being prevented, when we consider the character of some of the travellers who pass this road. ${ }^{52}$

An enclosure to that report from Henry Handyside, the Assistant Provincial Engineer, was more specific about the actual damage and confirmed Blackett's fears. He wrote that he was

sorry to observe on my return that some travellers had commenced the destruction of the house at the Guide for firewood. Two of the veranda posts have been taken away, causing the roof to droop. The want of firewood in this place will, I am afraid, cause the partial destruction of the house. ${ }^{53}$

After 1865, there is no letter of admonition to Carter to restore (or rebuild) the Acheron

52 The Provincial Engineer's Report on Public Works in the Amuri District and on the Main South Road, John Blackett, Provincial Engineer, 15 April 1865. NVP, 1865, a13-65, p 2.

${ }^{53}$ Enclosure to Provincial Engineer's Report to John Blackett Esq, Provincial Engineer from Henry

Handyside Assistant Engineer, 18 March, 1865. NVP 1865, a 13-65 p 5.
House of Refuge in the Nelson provincial archives. No letter of complaint as to its demise from frustrated travellers appears in either the provincial archives or newspapers. A letter printed in the Nelson Examiner from WTL Travers described the road from Canterbury to Nelson, traversed by him early in the winter of 1865 . Having described his night under a rock because the Acheron Accommodation House was unoccupied from May to late August, he wrote:

I proceeded to the Guide junction where I found two other men who had been prevented continuing their journey in consequence of the swollen state of the stream called Yarrow [Yarra] which runs into the Acheron about two miles above its junction with the Guide. ${ }^{54}$

While his letter described the ferocity of the rivers in flood, and the challenges of the track through that part of the country, it made no mention of a House of Refuge (or the men's frustration at not reaching it). Travers was an explorer and his description of the track and its landmarks was methodic and detailed. A year after its completion, the Acheron House of Refuge had apparently vanished without

${ }^{54}$ Travers "The Road from Canterbury to Nelson [letter to the editor]" p 3. trace. $^{55}$

\section{"Frontier Chaos"?}

While Wakefield's theory of systematic colonisation and its consequences was criticised by a series of scholars, ${ }^{56}$ until Fairburn's revisionist work and his theory of "frontier chaos,"57 few questioned whether European settlers had transplanted civilisation in New Zealand. Although Fairburn's theory was challenged, ${ }^{58}$ it seems validated by the furniture burning, crockery smashing and general lawlessness at the Tarndale ${ }^{59}$ and Acheron Accommodation Houses in 1863. It also potentially contextualises the demise of

${ }^{55}$ Area historian, W. J. Gardner reached this conclusion. Gardner The Amuri pp 208-209.

${ }^{56}$ See for instance Burns Fatal Success, Allan Nelson; History of Early Settlement and Miller Early Victorian New Zealand.

${ }^{57}$ Fairburn "The Ideal Society" pp 195-234.

${ }^{58}$ For example, Rollo Arnold in his 1990 paper,

"Community in Rural Victorian New Zealand" suggested that the New Zealand nineteenth-century settler world was a localised one, where "family, kin and neighbours worked together, first to occupy then to develop and maintain each new farming district." Arnold "Community in Rural Victorian New Zealand" $\mathrm{p}$ 3.

${ }^{59} \mathrm{~W}$. White to the Superintendent, 13 November 1863 1863/952 (SPN). 
the Acheron House of Refuge. ${ }^{60}$ In her challenge to Fairburn's theory, ${ }^{61}$ historian Caroline Daley wrote that the 1860s was definitely "the decade for men on the frontier and they punched and drank and sued their way through it."62 She concluded, however, that rather than a generally lawless and atomised settler society, frontier chaos was caused by "young single, working class men."63

While visitors books for accommodation houses on the Nelson to Canterbury Inland Stock Route were not found during my research, in the numerous letters to Provincial Government (including testimonials which carried names and signatures) newspaper accounts and personal correspondence, women travellers were not mentioned before the mid 1880s. ${ }^{64}$ The consensus of evidence suggests that through the 1860 s travellers staying at the accommodation houses on the Inland Stock Route were predominantly men and surges of behaviour ranging from loutish

${ }^{60}$ John Blackett: Provincial Engineer, NVP, 1865, a13-65.

${ }^{61}$ See also MacKay "The Orderly Frontier" pp147-157 and Belich Making Peoples pp 420-428.

${ }^{62}$ Daley "Taradale Meets the Ideal Society" p 145.

${ }^{63}$ Daley "Taradale Meets the Ideal Society" p 139.

64 "Report on Accommodation Houses" p 3. to lawless coincided with both the Nelson and West Coast goldrushes. While McAloon described the Nelson goldfields as "self policing communities,"65 loose knit groups of men travelling between centres of population and the goldfields showed less restraint. ${ }^{66}$ Most accommodation houses on the Inland Stock Route held Publican's Bush licenses ${ }^{67}$ and no matter what the construction defects, how numerous the guests, or mediocre the meals, a traveller could expect a plentiful supply of alcohol. ${ }^{68}$ The architecture of the acommodation houses was conducive to bawdy revelry. At the second Tophouse for example the small bedrooms ( 3 metres $\times 2$ metres) ${ }^{69}$ were accessed through the sitting room without a separating passage or transition space. When men travelling in the South Island high country (the frontier) were foist into close proximity and buoyed by alcohol, revelry had the potential to descend

${ }^{65}$ McAloon Nelson p 10.

${ }^{66}$ McAloon details the terror in the town of Nelson after the Maungatapu Murders of 1866. McAloon Nelson pp 76-77.

${ }^{67}$ The Acheron Accommodation House was the exception.

${ }^{68}$ See, Diary of J. C. Richmond 1863 pp 7-8 and Nathaniel Edwards to the Superintendent, 3 July 1874, NP 7 1874/849 (SPN).

69 "Report on Accommodation Houses" p 3. into chaos. It would appear that at the Acheron and Tarndale Accommodation Houses in 1863, it did. ${ }^{70}$

Daley's observation that these men were working class also bears consideration. Miners with means could travel by steamer to the West Coast but for those without capital, walking was the only choice. Historian, Mike Johnston described the lack of preparation and complete unfamiliarity with the climate and terrain of some prospectors when travelling to the gold fields. ${ }^{71}$ With reference to Wakamarina he wrote that "people who only a day or so earlier would never have considered going mining were now hurriedly joining the professional miners setting off for the new El Dorado."72 Jonhston described how ill-prepared many were for the journey.

All ages, degrees of fitness and occupations were represented. Some were only boys as young as 13 years of age, but despite their youth they carried blankets, shovel, tin dish and provisions. Others had no gear or, except perhaps for a bottle of alcohol, no provisions. One hopeful was so sick he was supported by a mate. ${ }^{73}$

\footnotetext{
${ }^{70}$ John Blackett: Provincial Engineer, NVP, 1865, a 13-65. ${ }^{71}$ Johnston Gold in a Tin Dish pp 64-66.

${ }^{72}$ Johnston Gold in a Tin Dish p 64.

${ }^{73}$ Johnston Gold in a Tin Dish p 65.
} 
Burning the timber support structure of the Acheron House of Refuge could be explained as lawless behaviour on a chaotic frontier. It may equally have been the result of the desperation for survival of ill-prepared men in freezing night time temperatures. By the mid 1860s both Canterbury and Nelson newspapers began to print warnings to would-be gold prospectors of the perils of high country climate and terrain. ${ }^{74}$ As this happened, from 1865 records of lawless behaviour at accommodation houses disappeared from internal provincial correspondence and official documents.

\section{Settler Reciprocity}

Fairburn also suggested that in the New Zealand settler world prior to 1890, "seldom ... were goods and services exchanged ... there was insufficient co-operation between neighbours to warrant much visiting."75 The first and second Tophouse, Tarndale and its successor the Rainbow Accommodation Houses were public buildings on the frontier, remote from any city and dispersed on an inland high country stock route. Their

${ }^{74}$ See for example "Route Overland the West Coast Goldfields" Lyttleton Times (6 March 1865) reprinted in Colonist (24 March 1865) p 5.

${ }^{75}$ Fairburn The Ideal Society pp 169-170. archival record offers the opportunity therefore, to consider Fairburn's suggestion.

The personal diaries and letters of those who stayed at these high country accommodation houses or kept them showed a surprisingly high level of reciprocity between travellers, keepers and neighbours. Father Antoine Garin's description of his stay at the first Tophouse recorded the unquestioned conventions of reciprocity in sharing food and drink and cooperation with fellow travellers in choosing beds, waking and making morning tea. ${ }^{76}$ This reciprocity was not confined to travellers. Minnie Landon Lane, who grew up at the Tophouse Telegraph Station from 1876, described her mother's late night dash on horse back to the Tophouse Accommodation House to assist with the birth of a baby. ${ }^{77}$ Realising the parents had no baby clothes she described how her mother "had to come back and rake out her precious hoarded up layettes, we two little girls had used."78

In 1874, the licence of the Tarndale Accommodation House was transferred to the

${ }^{76}$ Father Garin to Numa Garin, 22 February 1855 in Father Garin's Letters, 1850-1855.

${ }^{77}$ Lane to Newport (no date).

${ }^{78}$ Lane to Newport (no date) lower altitude Rainbow Accommodation House. ${ }^{79}$ Possibly the most irrefutable evidence of settler reciprocity manifest at the accommodation houses is recorded in Wairau Gorge Engineer, Jonathan Brough's accounts of the functioning of the Rainbow Accommodation House. Brough's diary entries show the role of the Rainbow Accommodation House served as a service centre for his isolated camp. It was there he kept his own and camp work horses ${ }^{80}$ and from there his camp was supplied with fresh meat, ${ }^{81}$ fruit, ${ }^{82}$ cheese, ${ }^{83}$ flour, ${ }^{84}$ newspapers, ${ }^{85}$ dynamite $^{86}$ (for blasting a track through Hell's Gate) and even, when a plague of rats

79 The Provincial Secretary to Mr John Kerr, 5 June 1874 NP 11/12 1874/392 (OSePn).

${ }^{80}$ Diary of Jonathan Brough, January 1882-December 1883, 3 February 1883, 18 February 1883.

${ }^{81}$ Diary of Jonathan Brough, January 1882-December 1883, 12 February 1883, 7 March 1883, 10 November 1883, 11 December 1883.

82 Diary of Jonathan Brough, January 1882-December 1883, 14 January 1883.

83 Diary of Jonathan Brough, January 1882-December 1883, 28 October 1883.

${ }^{84}$ Diary of Jonathan Brough, January 1882-December 1883, 11 April 1883.

${ }^{85}$ Diary of Jonathan Brough, January 1882-December 1883, 28 November, 1883.

${ }^{86}$ Diary of Jonathan Brough, January 1882-December 1883, 6 April, 1883. 
threatened camp supplies, a cat. ${ }^{87}$ The keeper, George Wright, held mail ${ }^{88}$ for the camp, and supplied more than the necessities of survival. In February 1883 Brough even noted in his diary, "George Wright came up from the Rainbow. Brought a gooseberry pie, red currant pie [and] raspberry pie."89 This initiative and kindness was repaid two months later when Mrs Wright rode up to the camp "in the face of a bitter snow storm," 90 needing ointment and painkillers for her husband and children who had the measles. While the supplying of the work camp was not an official duty of the accommodation house, it not only showed commercial initiative on the part of the keeper, but suggests a more general picture of reciprocity and mutual support. Despite the fact that high country settlers were dispersed and isolated, at the accommodation houses on the Inland Stock Route small, loose-knit communities shared an unwritten code of reciprocity.

${ }^{87}$ Diary of Jonathan Brough, January 1882-December 1883, 5 October, 1883.

${ }^{88}$ Diary of Jonathan Brough, January 1882-December 1883, 21 April, 1883.

${ }^{89}$ Diary of Jonathan Brough, January 1882-December 1883, 10 February, 1883.

${ }^{90}$ Diary of Jonathan Brough, January 1882-December 1883, 29 April, 1883.
Fairburn considered that before the 1880s New Zealand settlers had no places that fostered community. He wrote that "the lightning expansion of the frontier up to the 1880s pushed most colonists into new areas where they were strangers to one another, and where for an initial period no institutions existed to facilitate mixing and meeting."91 The high country between the Nelson Ranges and the Canterbury foothills remained in the 1860s the domain of extensive pastoral farming and on the Inland Stock Route showed little evidence of habitation. ${ }^{92}$ Part of this dispersed settlement pattern from the mid 1860s were the accommodation houses, a day's travel apart, some struggling to remain viable in the unforgiving South Island high country climate. If Fairburn's theories of an atomised society were correct, nowhere (apart perhaps from boundary shepherds' huts) would one expect to find this more evident.

Yet it is clear that even a dispersed

${ }^{91}$ Fairburn The Ideal Society p 192.

${ }^{92}$ Under examination by the Railways Commission, Charles Elliott explained that between the Tophouse and Hanmer there were in 1883 only four places people lived: Tarndale, Clarence [the Acheron Accommodation House], Richmond Dale and Rainbow. Charles Elliott examined by Mr Henderson, 327, p 22 Section D2, AJHR Vol I, D-G 1883. community acted as a "village," a term used by historian Rollo Arnold who wrote that "New Zealand's founding stock was drawn predominantly from village life of the Old World" and they bought a "village outlook" with them. ${ }^{93}$

The first Tophouse was the venue for a meeting on education, ${ }^{94}$ the third Tophouse a point of rural mail exchange, a church and a school, ${ }^{95}$ the Tarndale, an area pub and courthouse $^{96}$ and the first Rainbow Accommodation House the local supply store. ${ }^{97}$ Even though these "villages" lacked the population for established institutions with functionally specific buildings, people gathered at the accommodation houses and were bound by ideals of reciprocity. While a visual inspection of the Nelson provincial high country (or a current map of its archaeology and buildings between 1860-90) may serve as validation of Fairburn's hypothesis, a closer archival inspection of the

${ }^{93}$ Arnold New Zealand's Burning p 118.

${ }^{94}$ Father Garin's Diaries, 1850-1859, October 1856.

95 Tomlinson to Newport, unpublished manuscript, 1981.

${ }^{96}$ Nathaniel Edwards to the Superintendent, 3 July 1874, NP 7 1874/849 (SPN) and "The Murder and Suicide at Tarndale" p 8.

${ }^{97}$ Diary of Jonathan Brough, January 1882-December 1883, 12 February 1883-28 October 1883. 
social transactions at these accommodation houses reveals these were the focus for local communities.

\section{Conclusion}

The surge of lawlessness experienced at the most remote accommodation houses on the Nelson to Canterbury Inland Stock Route in 1863 vindicated George Rutherford's observation that there were "many bad characters moving about in these digging times."98 It was chaotic behaviour and the South Island high country was, in the 1860s, still frontier. Although the destruction of the Acheron House of Refuge appeared part of this surge of lawlessness it could equally be attributed to the desperation of ill-equipped men to survive. Whether driven by lawlessness or cold and hunger however, this paper has argued that these incidents were short-term, perpetrated by men in transit and could not be said to be illustrative of the generalised social malaise of "frontier chaos." Archival evidence from the accommodation houses on the Nelson to Canterbury Inland Stock Route is fragmentary but it consistently shows that travellers, keepers and neighbours

${ }^{98}$ George Rutherford to Superintendent, 2 September 1863, NP 7 1863/666 (SPN) shared an unwritten code of reciprocity. Apart from the Tophouse Telegraph Station there were no functionally-specific community buildings in the high country between Nelson and Canterbury before 1890 but the accommodation houses fulfilled the function of meeting venue, church, school, general store, pub, postal centre and courthouse. They were neither lonely nor lawless but important centres for dispersed local communities. 


\section{REFERENCES}

Appendix to the Journal of the House of Representatives, Vol. 2. 1883, Elma Turner Library, Nelson.

Arnold, Rollo "Community in Rural Victorian New Zealand" The New Zealand Journal of History, (1990) 24(1):3-21.

Arnold, Rollo New Zealand's Burning: The Settlers' World in the Mid 1880s: Victoria University Press, 1994.

Barker, Lady Station Life in New Zealand New Zealand: Random House, 2000; first published in England, 1870.

Belich, James Making Peoples. A History of the New Zealanders from Polynesian Settlement to the End of the Nineteenth Century Auckland: Penguin Books (NZ) Ltd, 1996.

Burnard, Trevor, "An Artisanal Town: The Economic Sinews of Christchurch" Cookson, John and Dunstall Graeme (eds) Southern Capital Christchurch Towards a City Biography 1850-2000 Christchurch: Canterbury University Press, 2000.

Diaries of Jonathan Brough: Diaries, reports concerning surveying and road making in the Wangapeka and Karamea Rivers and the Wairau Gorge,1882-1899, (18 April 1882 - 4 January 1883 \& 7 January 1883 30 December 1883). qMS-0274, Archives and Manuscripts, Alexander Turnbull Library Wellington.

Cookson, John "Pilgrims' Progress - Image Identity and Myth in Christchurch" Cookson, John and Dunstall Graeme (eds) Southern Capital Christchurch Towards a City Biography 1850-2000 Christchurch: Canterbury University Press, 2000.

Daley, Caroline "Taradale Meets the Ideal Society and its Enemies" The New Zealand Journal of History (1991) 25(2):129-146.

"Death by Drowning" Colonist (28December 1860):3.

Diary of J. C. Richmond 1863, Journey from Nelson to the Hanmer Plains, Nelson Provincial Museum Archives and Manuscripts Library.
Fairburn, Miles The Ideal Society and its Enemies. The Foundations of Modern New Zealand Society 1850-1900 Auckland: University of Auckland Press, 1989.

"Father Garin's Diary and Mission Notes 1850-1859" Translated from original held in Marist Archives Rome by Peter Tremewan, 20032004. St Mary's Parish Archives, Nelson.

"Father Garin's Letters 1850-1859" Translated from original held in Marist Archives Rome by Peter Tremewan, 2003-2004. St Mary's Parish Archives, Nelson.

Fooks, C.E. "Map of Christchurch, Canterbury, New Zealand, 1862'. Christchurch City Libraries Cartographic Collection.

Gardner, W.J. The Amuri: A County History Culverden [N.Z.]: The Amuri County Council, 1983; first published 1956.

Gully, John "Interior of Tarndale Accommodation House 1860s" Ref: A178-006, Drawings and Prints Collection, Alexander Turnbull Library, Wellington, New Zealand.

Hobhouse, Elizabeth \& Oxford Association for Assisting The Bishop of Nelson, An Account of the Diocese of Nelson, New Zealand Oxford; London: John Henry and James Parker, 1862.

Johnston, Mike Gold in a Tin Dish. The Search for Gold in Marlborough and Eastern Nelson. Volume One. The History of the Wakamarina Goldfield: Nikau Press, 1992.

Lane, Minnie Landon to J. N. W. Newport (no date). AG 144, Nelson Provincial Museum Archives and Manuscripts Library.

McAloon, Jim Nelson: A Regional History Whatamango Bay: Cape Catley Ltd; Nelson City Council, 1997.

McAloon, Jim "James Jenkins Lecture" Nelson Historical Society (Incorporated) Journal (1998):3-11.

MacKay, Duncan "The Orderly Frontier: The World of the Kauri 
Bushmen1860-1925" The New Zealand Journal of History (1991) 25(2):147-157.

Miller, John Early Victorian New Zealand: A Study of Racial Tension and Social Attitudes 1839-1852 Oxford: Oxford University Press, 1958.

Morrison, J.P. The Evolution of a City: The Story of the Growth of the City and Suburbs of Christchurch the Capital of Canterbury in the years from 1850 to 1903 Christchurch [N.Z.]: Christchurch City Council, 1948.

"The Murder and Suicide at Tarndale" Nelson Examiner (5March 1868):8.

Nelson, New Zealand Votes and Proceedings of the Provincial Council (NVP) Session IX 1862.

Nelson, New Zealand Votes and Proceedings of the Provincial Council Session XII 1864.

Nelson, New Zealand Votes and Proceedings of the Provincial Council Session XIII 1865.

"The Nelson Examiner: Nelson, April 6, 1850" Nelson Examiner (6 April 1850):2.

"The Nelson Examiner: Nelson, January 26, 1850" Nelson Examiner (26 January, 1850):2.

Nelson Province Series 7 [NP 7] (Inward Letters to the Superintendent $(\mathrm{SPN}) /$ Secretary $(\mathrm{SePN})$ of the Province of Nelson), Archives New Zealand/ Te Rua Mahara o Te Kawanatanga, Head Office, Wellington. (NP 7 1862/395; NP 7 1862/599; NP 7 1863/42; NP 7 1863/666; NP 7 1863/952; NP 7 1864/751; NP 7 1865/808; NP 7 1874/849)

Nelson Province Series 11 [NP 11] (Outward Letters from the Superintendent (SPN)/ Secretary (OSePN) of the Province of Nelson) NP 11/4 1862/395 Archives New Zealand/ Te Rua Mahara o Te Kawanatanga, Head Office, Wellington.

Olssen, Erik "Where to from Here? Reflections on the Twentieth-Century Historiography of Nineteenth-Century New Zealand" The New
Zealand Journal of History (April 1992) 26(1):54-77.

Olssen, Erik "Mr Wakefield and New Zealand as an Experiment in Post Enlightenment Experimental Practice" The New Zealand Journal of History (October 1997) 31(2):197-218.

Phillips, Jock A Man's Country? The Image of the Pakeha Male: A History [Auckland, N.Z.]: Penguin Books, 1987.

"Report on Accommodation Houses" Colonist (19 November 1886) p 3.

Scotter, W.H. "The Superintendencies of W.S. Moorhouse (1857-1863; 1866-1868) and Samuel Bealey (1863-66)" N.C. Phillips, D. Macmillan \& W.J. Gardner (eds) A History of Canterbury Vol. II: General History, 1854-76 and Cultural Aspects, 1850-1950 Christchurch: Whitcombe and Tombs Ltd., 1971.

Tomlinson, J. E. to J. N. W. Newport, 1981. AG 144, Nelson Provincial Museum Archives and Manuscripts Library.

Travers, W.T.L. "The Road from Canterbury to Nelson [letter to the editor]" 1 June 1865 Nelson Examiner (6 June 1865):3.

Webb, L.C. "The Canterbury Association and its Settlement" J. Hight \& C.R. Straubel (eds) A History of Canterbury Volume I: To 1854 Christchurch: Whitcombe and Tombs Ltd., 1957. 